Marquette University

e-Publications@Marquette

$3-1-2013$

\title{
The Discretionary Effect of CEOs and Board Chairs on Corporate Governance Structures
}

Matteo P. Arena

Marquette University, matteo.arena@marquette.edu

Marcus V. Braga-Alves

Marquette University, marcus.braga-alves@marquette.edu

Accepted version. Journal of Empirical Finance, Vol. 21 (March 2013): 121-131. DOI.

NOTICE: this is the author's version of a work that was accepted for publication in Journal of Empirical Finance. Changes resulting from the publishing process, such as peer review, editing, corrections, structural formatting, and other quality control mechanisms may not be reflected in this document. Changes may have been made to this work since it was submitted for publication. A definitive version was subsequently published in Journal of Empirical Finance, Vol. 21 (March 2013): 121-131. DOI. 


\title{
The Discretionary Effect of CEOs and Board Chairs on Corporate Governance Structures ${ }^{\text {it }}$
}

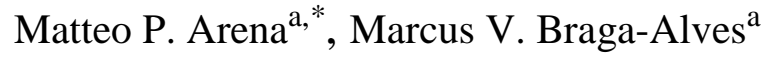 \\ ${ }^{a}$ College of Business Administration, Marquette University, Milwaukee, WI 53201, USA
}

\begin{abstract}
In this study we analyze the effect of latent managerial characteristics on corporate governance. We find that CEO and board chair fixed effects explain a significant portion of the variation in board size, board independence, and CEO-chair duality even after controlling for several firm characteristics and firm fixed effects. The effect of CEOs on corporate governance practices is attributable mainly to executives who simultaneously hold the position of CEO and board chair in the same firm. Our results do not show a decline in CEO discretionary influence on corporate governance after the enactment of the Sarbanes-Oxley Act and stock exchange governance regulations.
\end{abstract}

Keywords: corporate governance, board of directors, manager fixed effects, Sarbanes-Oxley Act JEL Classifications: G34, G38, J24, C23

* The authors thank Thomas Boulton, Moshe Cohen, Manoj Kulchania, James McGibany, Sarah Peck, Anthony Pennington-Cross and seminar participants at Marquette University and at the Midwest Finance Association (New Orleans) for valuable comments. Any remaining errors or omissions remain the responsibility of the authors.

* Corresponding author. Tel.: + 1-414-288-3369; fax: + 1-414-288-5756.

E-mail addresses: matteo.arena@marquette.edu (M. Arena), marcus.braga-alves@marquette.edu (M. BragaAlves). 


\title{
The Discretionary Effect of CEOs and Board Chairs on Corporate Governance Structures
}

\begin{abstract}
In this study we analyze the effect of latent managerial characteristics on corporate governance. We find that $\mathrm{CEO}$ and board chair fixed effects explain a significant portion of the variation in board size, board independence, and CEO-chair duality even after controlling for several firm characteristics and firm fixed effects. The effect of CEOs on corporate governance practices is attributable mainly to executives who simultaneously hold the position of CEO and board chair in the same firm. Our results do not show a decline in CEO discretionary influence on corporate governance after the enactment of the Sarbanes-Oxley Act and stock exchange governance regulations.
\end{abstract}




\section{Introduction}

"In my experience, few directors in modern times have seen their interests as separate from those of the CEO, who effectively appointed them and, presumably, could remove them from future slates of directors submitted to shareholders." Alan Greenspan at the Stern School of Business, March 26, 2002.

Despite anecdotal evidence and academic studies on the discretionary power of CEOs in selecting board of director candidates (e.g., Mace (1971), Hermalin and Weisbach (1998) and Shivdasani and Yermack (1999)), the financial economics and corporate governance literature lack a detailed empirical examination of the influence of CEO effects on a broad range of internal corporate governance structures. Our study addresses this gap by examining for the first time the effect of the variation in non-readily measurable personality traits and managerial styles of CEOs and board chairs, also known as managerial heterogeneity, on corporate governance.

Specifically, in this study we investigate the role of managerial heterogeneity in explaining board size, board independence, and the CEO-chair duality, which have significant influence on financial and strategic corporate decisions. We also examine whether CEO-specific heterogeneity can explain the variation across firms in the strength of shareholder rights, which are represented in this study by a modified version of the index created by Gompers et al. (2003). Additionally, we investigate whether the Sarbanes-Oxley Act of 2002 (SOX) along with the NYSE and Nasdaq new governance regulations approved by the Securities and Exchange Commission (SEC) in 2003 have reduced managerial discretion on governance practices in recent years. 
This study contributes to two streams of the recent financial economics and corporate governance literature. First, we complement studies of the effect of managerial characteristics on corporate decisions (e.g., Bertrand and Schoar (2003) and Graham et al. (2011)). More specifically, we add an important dimension to the literature on determinants of board structure. Most of the existing finance studies on governance focus on the influence of firm characteristics rather than managerial effects on board structure (e.g., Coles et al. (2008) and Link et al. (2009)). Second we contribute to studies on the effects of the Sarbanes-Oxley Act (SOX) enacted in 2002 and the new rules approved by the SEC in 2003 on corporate governance and corporate decision making (e.g. Link et al. (2009) and Kang et al. (2010)). Overall, our study contributes to the ongoing discussion regarding the influence of CEOs on the internal mechanisms of control of their firms. This debate has continued after SOX and is likely to have a significant effect on how new legislative norms and SEC rules will be mandated to address corporate ethical issues.

Our results show that $\mathrm{CEO}$ and chairperson characteristics have a significant effect on the variation in board composition (board size and independence) and the decision to join or separate the CEO and board chair positions. The significant effect of CEOs on governance practices appears to be mainly attributable to CEOs who also hold the board chair position. When we analyze fixed effects for CEOs who are not board chairs, the addition of CEO fixed effects to our regressions does not add explanatory power. Powerful CEOs who assume also the role of chair of the board have the ability to significantly influence governance policies. We do not find that Sarbanes-Oxley and stock exchange governance regulations have significantly decreased the effect of CEOs on corporate governance.

Our finding related to the CEO-chair of the board duality is worth of note. While in many countries the separation of the CEO and chair of the board positions is the norm (e.g. 
Canada, Australia, Britain and much of continental Europe), the majority of U.S. public corporations combine the two positions. Despite pressure from international institutional investors to separate the two jobs, the CEO-chair duality is one of the few significant dimensions of internal corporate governance that SOX and stock exchange governance new regulations have left untouched. ${ }^{1}$

Our findings result from an empirical analysis of the effect of the variation in non-readily measurable personality traits and managerial styles on corporate governance based on the estimation of CEO and chair of the board fixed effects regressions. In assessing the significance of managerial heterogeneity on corporate governance, we control for several firm characteristics that are related to corporate governance. Additionally, we investigate whether new governance regulations implemented in 2002 and 2003 have reduced managerial discretion on governance practices. Finally, we implement a battery of tests to address concerns about a possible endogenous relation between manager-specific characteristics and corporate governance.

Similar to Bertrand and Schoar (2003), we restrict our sample to firms that switch CEOs at least once during the sample period. This sample restriction is required to separate manager fixed effects from firm fixed effects because the effect on corporate practices of a CEO who never changes firm cannot be estimated separately from his firm fixed effect. In this case, there would be perfect correlation between manager fixed effects and firm fixed effects. Moreover, even though it would be statistically possible to extend the analysis to CEOs who manage only one firm for only a portion of the entire sample period, that approach would generate the risk of obtaining spurious results due to unobservable factors that are correlated with manager fixed effects. To avoid this potential risk, we do not extend our sample to those CEO-firm pairs.

\footnotetext{
1 "Someone to watch over them", The Economist, October 15, 2009.
} 
Drawing causality between manager-specific heterogeneity and board structure or managerial entrenchment requires careful consideration because the relation between governance structures and CEO heterogeneity might be spurious. For example, changes in board structures and shareholders rights might have been decided previous to the hiring of the new CEO but their implementation coincided with the CEO arrival. In this case, if the model specification adequately captures the effect of all other relevant exogenous variables, we might not find any remaining effect due to managerial heterogeneity. Another possibility is a potentially endogenous relation between managerial characteristics and corporate governance affecting the results of this study due to, for example, reverse causality. It could be argued that managerial heterogeneity does not explain the variation in corporate governance. Instead, firms optimally choose managers who are the best match for their corporate governance structures.

We use firm fixed effects to control for time-invariant, unobserved characteristics that are omitted from our model specification. Moreover, our independent variables control for the possibility that firms with CEO-chair duality are particular types of firms along the dimensions underscored by the firm characteristics proxied by our control variables. We also partially control for reverse causality by lagging the independent variables by one fiscal year. We then address concerns about endogeneity more thoroughly in two additional ways. First, in similar vein to Richardson et al. (2003), we examine changes in governance structures for CEOs and chairs with tenures of at least two years. We essentially focus on those executives who might have an improved ability to influence the governance policy variables due to longer tenure. Second, we adopt the Bertrand and Schoar's (2003) residual regressions and placebo method.

Our second robustness test consists of a parametric analysis based on residual regression to examine the persistence of managerial effects on governance. We regress the executive's 
average residual in his second firm on his average residual in the first firm. We find a positive and statistically significant relationship between a CEO or chair residual in his last job and his residual in his first job for the majority of our governance variables. We then regress preappointment residuals, which assume that each manager in our sample joins his second firm three years before and leaves it on the actual appointment date, on the true average residuals in the first firm. The placebo results are not significant. Overall, the evidence offered by our robustness tests suggests that endogeneity is not driving the findings of this study.

The remainder of this paper is organized as follows. Section 2 reviews prior related literature and develops the hypotheses. Section 3 describes our sample selection procedure and provides descriptive statistics for our sample. Section 4 presents our multivariate results. Section 5 discusses our robustness tests. Section 6 summarizes and concludes.

\section{Related literature and hypotheses development}

The variation in managers' unobservable characteristics, i.e. heterogeneity due to different personality traits and managerial styles, has a significant effect on a wide range of corporate policies. Bertrand and Schoar (2003) find that manager fixed effects are important determinants of observed variation in investment, financial, and organizational practices of firms. According to the authors, these effects are especially important in decisions related to acquisitions, diversifications, dividend policy, interest coverage, and cost-cutting initiatives. Richardson et al. (2003) examine whether individual board members' preferences or skills are reflected in corporate policy choices and find that director fixed effects also appear to explain variation in firms' governance, financial, disclosure, and strategic policies. Frank and Goyal (2009) show that managerial behavior dominates conventional factors in their ability to account 
for cross-sectional differences in leverage. Finally, Graham et al. (2011) examine the relation between manager heterogeneity and executive compensation and provide evidence that managerial fixed effects have a significant role in the level of executive compensation. The authors argue that ignoring these effects could result in biased coefficients when estimating the compensation equation. The methodology allowed the authors to estimated managerial fixed effects not only for managers who change firms but also for some managers who do not.

Academic and anecdotal sources suggest that the CEO and the chair of the board play an important role in the processes that direct and control their organizations. One important issue in corporate governance research is the extent to which CEOs influence the board of directors, who should monitor the firm's executives but are unlikely to challenge the power and authority of those who are often responsible for their nominations to the board. Mace (1971), a board director himself, states that executives "determine in large part what the board of directors does or does not do" and mentions that other authors have also noted this relationship (e.g., Berle and Means (1932), Mason (1958), and Galbraith (1967)). Hermalin and Weisbach (1998) examine the relation between board effectiveness and the process of director choice. They argue that board independence is determined from negotiations over the balance of power. Shivdasani and Yermack (1999) show that independent directors are less likely to effectively monitor executives when the CEO is involved in the director selection. Florou (2005) find a significant relation between chair removal and CEO dismissal in the U.K. She suggests that the replacement of the chair of the board in these cases enables subsequent governance restructuring, which requires new perspectives and abilities. More recently, Boone et al. (2007) present evidence consistent with the board independence resulting from a negotiation between the CEO and the board of directors. 
CEOs' and chairs' influence on the nomination process and board independence is, however, just one instance of their influence on the design of a firm's governance structures. CEOs can affect other dimensions of internal mechanisms of control such as board size, CEOchair duality, and provisions that restrict shareholder rights. For example, Lipton and Lorsch (1992) and Jensen (1993) argue that smaller boards are more efficient at reducing agency costs because of coordination and process problems associated with a larger number of directors. Yermack (1996) provide empirical evidence that small boards are more effective in monitoring managers and more likely to fire poor performing CEOs. Goyal and Park (2002) present evidence that CEOs are more likely to be replaced due to poor performance if the CEO is not the chairman of the board. If poor performing CEOs are less likely to be replaced by larger boards and when they are chair of the board of directors, we should see evidence of a significant relation between top executives' managerial heterogeneity and relevant corporate governance structures. Therefore, we present our first hypothesis as follows:

Hypothesis 1: CEO and chair heterogeneity explains a significant share of the variation in governance structures, even after controlling for firm characteristics.

For many years, market participants and institutions have been pressuring U.S. regulators to separate the titles of CEO and chair of the board of directors. Fama and Jensen (1983) argue that concentration of the management and control decisions under the same person reduces the effectiveness of supervision by the board of directors. Jensen (1993) argues that CEOs cannot oversee the process of hiring, firing, evaluating, and compensating their company's managers apart from personal interests. Core et al. (1999) and Cyert et al. (2002) show that CEOs receive higher compensation when they are also board chairs. Felton (2004a) indicates that, for directors 
and institutional investors, the separation between the roles of chairman and CEO is the most important item to be discussed since the passage of SOX. And Felton (2004b) suggests that the separation of the two titles improves corporate governance and reduce the risk of corporate fraud. Adams et al. (2005) provide evidence that firm performance is more variable when CEOs are more powerful and have greater influence on the company's decision-making process. We state our second hypothesis as follows:

Hypothesis 2: CEOs who also hold the chair of the board position have larger discretionary power on governance structures.

Following a series of accounting scandals, the U.S. Congress enacted the Sarbanes-Oxley Act (SOX) in July 2002 to improve financial disclosure and strengthen internal governance mechanisms for all U.S. public companies. SOX placed additional responsibility on senior executives for the accuracy and completeness of financial reports with more severe penalties for corporate fraud. In November 2003, the NYSE and the Nasdaq implemented new rules approved by the SEC establishing a stricter definition for independent directors and requiring a majority of directors on listed companies' boards to satisfy that definition. These rules also require that the audit, compensation, and nominating committees must consist of only independent directors. SOX and these stock exchange reforms have had important consequences. Link et al. (2009) examine board structure trends and find that the passage of SOX accelerated the already existing trend towards more independent boards while reversed the previous trend towards smaller boards. Post-SOX, board committees meet more often, and directors are more likely to be lawyers, consultants, financial experts, and retired executives. SOX and the exchange reforms have also had unintended consequences. Bargeron et al. (2010) show that risk-taking by 
managers has significantly decreased since SOX and that the magnitude of this decline is related to board structure, firm size, and R\&D expenditures. Kang et al. (2010) find robust evidence that managers adopted a more cautious attitude toward corporate investment by using a higher discount rate after the passage of SOX. The authors also find that the effects of SOX are even more significant for well-governed firms with a credit rating. Since SOX and the new regulations are intended, among other things, to reduce managerial control rent and align managers' and shareholders' interests, our third and final hypothesis is that:

Hypothesis 3: Governance reforms have reduced the effect of managerial characteristics on corporate governance.

\section{Sample and descriptive analysis}

\subsection{Sample Selection}

Our sample combines data on the identity of CEOs and board chairpersons, consolidated financial accounting data, stock-related data, and corporate governance data. We compile our manager-firm panel data sample as follows. The sample selection starts with all firms in the RiskMetrics, formerly known as Investor Responsibility Research Center (IRRC), database for the calendar years between 1996 and 2009. From the RiskMetrics Directors dataset, for each firm-year observation we obtain information regarding board size and number of independent directors. Since RiskMetrics' employment title variable does not necessarily indicates that the director has that title in the firm, CEO and chairperson information is hand-collected by reviewing proxy statements posted on the SEC's Edgar filings database with meeting dates corresponding to the dates provided by RiskMetrics. 
Board composition data is then merged with the annual Compustat and CRSP databases to obtain financial accounting and stock information to generate the other independent variables that previous studies have found related to corporate governance characteristics. These variables are the firm's market value of equity, market-to-book ratio, free cash flow scaled by total assets, the standard deviation of monthly stock returns over the previous fiscal year, annual industryadjusted earnings before interest and taxes scaled by total assets and averaged over a two-year period, long-term debt divided by total assets, the number of business segments, and firm age, defined as the number of years since the stock first appears in CRSP.

From the RiskMetrics Governance dataset, formerly known as the IRRC Takeover Defense database, we obtain information regarding 24 state, charter and bylaw provisions that limit shareholder rights from 1996 to 2006 . We then construct a modified version of the Gompers et al.'s (2003) governance index (G-index). We exclude from the original index six provisions that depend on the laws of the state of incorporation of the firm and that, therefore, are less subject to managerial discretion (i.e. business combination, control-share acquisition and cash-out, directors' duties, fair-price and antigreenmail laws). The modified version of the index includes, therefore, 18 of the $24 \mathrm{G}$-index provisions.

While the majority of our multivariate tests make use of the entire sample spanning from 1996 to 2009, the regressions with the modified G-index as the dependent variable are based on observations from 1996 to 2006 due to a modification in how Riskmetrics accounts for shareholder provisions. Before 2007, RiskMetrics used the Investor Responsibility Research Center (IRRC) as data source. Currently, instead, it uses data from the Institutional Shareholder Services (ISS) collection system. This change has a significant impact on RiskMetrics data and makes the most recent period not directly comparable to previous years. 


\subsection{Descriptive Statistics}

Table 1 presents descriptive statistics of our samples. As shown in Panel A, our CEO sample consists of 140 CEOs who switch firms at least once during our sample period. The great majority (133) switched firms only once. Six CEOs managed three companies and one CEO managed four different firms between 1996 and 2009. The chairperson sample consists of 249 chairpersons. Most of the board chairs chaired the boards of two firms (224), 23 chairpersons chaired three boards, one chaired four, and one presided over six different boards. As shown in

panel B, the CEO sample consists of 266 unique firms while the chairman sample consists of 480 firms. Overall, our CEO sample consists of 842 CEO-year observations and our chairman sample consists of 1,772 chair-year observations.

Several recent studies show a significant relation between firm characteristics and internal corporate governance systems. Corporate boards tend to increase in size and add more outsiders as operations of a firm expand (Boone et al. (2007)). Large firms have large boards with more outside directors (Linck et al. (2008)). More complex firms (i.e., larger, more diversified firms with higher leverage) benefit from larger boards (Coles et al. (2008)). Therefore, we include several firm-level control variables in our analysis. Table 2 presents the descriptive statistics for the samples with CEOs who switch firms at least once and with chairpersons who were the chair of the board in at least two firms during the sample period. To generate the statistics reported in Table 2, we first calculate firm averages across time and then the means, medians and standard deviations of those firm averages. Panel A of Table 2 presents descriptive statistics for firm-specific control variables that have been found to significantly affect governance characteristics by extant studies in corporate governance. FCF is free cash- 
flow, defined as cash flow from operations minus dividends for preferred and common stocks divided by total assets; MVE is the market value of equity, defined as stock price at the end of the fiscal year times the number of common shares used to calculate EPS; LTD is long-term debt divided by total assets; ADJEBIT is the two-year average of EBIT minus the industry median; NSEGS is the number of business segments; STDEV is the standard deviation of monthly stock returns over the previous fiscal year, and AGE is the firm's age in years.

Panel B presents the descriptive statistics of governance characteristics from which we generate the dependent variables in our multivariate tests. Board size is the number of directors on the board. Independents (insiders) refer to the number of independent (insider) directors on the board. ${ }^{2}$ Ceo\&Chair is a binary variable that identifies CEOs who are also the chairperson of the board of directors in the same company. The modified G-index includes only 18 of the 24 provisions that originally constituted Gompers et al.'s (2003) index as 6 components of the Gindex are less subject to managerial discretion.

\section{Multivariate Analysis}

The multivariate analysis consists of regressions that include CEO or chairperson indicator variables for each executive who is the CEO or the chair of the board for at least two different firms during the sample period. Each of these indicator variables assumes the value of one for a firm-year observation when a specific manager acts as CEO or chairperson for that firm in a fiscal year.

Specifically, our multivariate analysis consists of the following regressions:

$$
y_{i, t+1}=g\left(X_{i t} \beta+\alpha_{t}+\gamma_{i}+\lambda_{j}\right)+\varepsilon_{i t}
$$

\footnotetext{
${ }^{2}$ RiskMetrics classifies directors as insiders, affiliated outsiders, and independents.
} 
where $\mathrm{g}($.$) is the conditional mean function. Here g(x)=x$ for the linear model and $g(x)=$ $\exp (x) /[1+\exp (x)]$ for the logit model. The dependent variable, $y_{i, t+1}$, is one of the corporate governance variables (i.e., board size, proportion of independent directors, $\mathrm{CEO} /$ chairperson duality, and the modified G-index), $X_{i t}$ is a vector of time-varying firm level characteristics, $\alpha_{\mathrm{t}}$ are year fixed effects, $\gamma_{i}$ are firm fixed effects, and $\varepsilon_{i t}$ is the error term. $\lambda_{j}$ are the fixed effects for the CEO or, alternatively, for the chairperson of the board. We estimate conditional fixed effects logit regressions for $\mathrm{CEO} /$ chairperson duality and linear fixed effects regressions for all the other dependent variables. In order to statistically assess the incremental effect of manager-specific effects over firm characteristics on corporate governance practices, we generate F-statistics and chi-square statistics from tests of the joint significance of $\mathrm{CEO}$ and chairperson fixed effects to test the null hypothesis that all the manager fixed effects are zero. We also compare the adjusted and pseudo $\mathrm{R}^{2}$ of regression specifications with and without manager fixed effects. We estimate regression (1) with firm fixed effects but without CEO or chairperson fixed effects, and then with both firm effects and CEO (or chairperson) effects.

Table 3 presents the results of our fixed effects regressions. In addition to firm fixed effects, we control for several control variables that the extant literature has found related to corporate governance characteristics (e.g., Linck et al. (2008)).

Panel A shows that CEOs have a significant effect on all of the governance characteristics under examination. In the regression in which board independence is the dependent variable, CEO fixed effects are significant at the $1 \%$ level over the control variables, year, and firm effects. CEO characteristics have also a significant effect on board size and an even stronger effect on the decision to join or separate the chairperson and CEO positions. The introduction of CEO fixed effects in the model drastically increases the pseudo $\mathrm{R}^{2}$, suggesting 
that CEOs have large discretionary power on the decision to assume the chairmanship of the board of directors of their firms. Finally, the results of the modified governance index regression show a significant effect of CEO characteristics on the adoption of corporate bylaws. This result is worthy of note considering that previous papers have documented a lack of significant changes in governance shareholder provisions over time at the firm level. ${ }^{3}$

Panel B presents the chairperson fixed effects regressions results. Chairperson characteristics have a significant effect on board independence, board size, and CEO-chair duality at the $1 \%$ level. In the regression in which the modified G-index is the dependent variable, chairperson effects are significant at the 5\%. Overall, the results of Table 3 show that both CEOs and chairpersons of the board have a significant influence on the governance of their firms. Unreported coefficients on the control variables have sign and significance consistent with the literature. ${ }^{4}$

In Table 4 we partition our sample into two sub-periods: before and after the ratification of the Sarbanes-Oxley act (pre- and post-SOX, respectively). SOX and the governance rules introduced by the NYSE and Nasdaq at approximately the same time required a majority of independent directors on the board and aimed to limit the power of the CEO on board decisions by, among other things, requiring full independence of audit, compensation, and nomination committees. By partitioning the sample into these two periods, we are able to investigate if new governance regulations enacted by the NYSE and Nasdaq in 2003 along with SOX have reduced the managerial effect on corporate governance practices.

\footnotetext{
${ }^{3}$ We replicate the G-Index regressions using the whole G-Index consisting of all 24 provisions, which includes six state provisions. The "full" G-Index results are very similar to the modified G-Index results of Table 3 with the exception of the magnitude of the p-values. Including the six state provisions slightly reduces the significance of the executive fixed effects. Due to the difficulty for executives to opt out of state provisions, this outcome is not surprising.

${ }^{4}$ Tables containing coefficients and significance of the control variables are available upon request.
} 
Panel A shows that CEO effects on board independence, board size and CEO-chair duality are significant post-SOX while the CEO effects in the CEO-chair duality and modified G-index regressions are significant pre-SOX. Panel B shows that chairperson effects on board independence and CEO-chair duality are significant post-SOX while the effects in board size, CEO-chair duality and modified G-index regressions are significant pre-SOX. It is important to note that fixed effects regressions with year, firm and manager fixed effects require a large amount of degrees of freedom, and that reducing the sample period and sample size by about half strongly reduced the power of our tests. However, the results presented in Table 4 provide evidence that, at a minimum, SOX did not reduce the effect of CEO heterogeneity on governance and are consistent with those presented in papers that question the effectiveness of that act. Ghosh et al. (2010), for example, find no evidence that earnings management declined following SOX.

CEOs who also chair the board of their own companies hold more decision-making power (Adams et al. (2005)) and could possibly have more discretional power on modifying firm's governance. In Panel A of Table 5, we examine this conjecture by restricting our analysis to CEOs who are also chair of the board for at least one of the two firms they lead during the sample. Consistent with our conjecture, we find that these CEOs have a significant effect on board size, board independence, and G-index despite the lower power of these tests due to the smaller sample size. The "powerful CEO" effects are significant at the $1 \%$ level for board independence and G-index and at the $10 \%$ level for board size.

Conversely, panel B of Table 5 shows that when we restrict our sample to CEOs who do not hold the board chairmanship for at least one of the two firms they lead during the sample period, the effect is not significant for board independence and board size. Overall, the results in 
panel A and B of Table 5 present strong evidence that CEOs that are also board chairpersons have a significantly stronger influence on the design of the internal governance of their own firms. ${ }^{5}$

The significant results of our main chair fixed effects regressions presented in panel B of Table 3 could be caused by those chairpersons who are also CEOs of the same firm. In order to verify that our chair fixed effects results are not driven by chairpersons who are also CEOs, we re-estimate the chair fixed effects regressions for the subsample of chairpersons that do not hold the CEO position for the firms for which they chair the board during our sample period ("pure chairs"). Panel C of Table 5 presents the results for chairperson of these fixed effects regressions. The chair effects results hold for board size and G-index when considering this subsample, confirming that our chair effect results are not exclusively driven by executives who hold both the chairpersons and CEO position.

\section{Robustness Tests}

The significant relation between managerial heterogeneity and governance structure documented in the previous section does not dispel concerns about spurious correlation and endogeneity. We may observe a spurious correlation between the response and the explanatory variable if some firm-specific characteristics that affect both are not present in the specification. For example, changes in board structures and shareholders rights might have been decided and a new CEO hired due to the same unobserved factors. Therefore, we use fixed effects estimations to control for firm-specific, unobserved characteristics. As argued by Chi (2005), fixed effects

\footnotetext{
5 The samples of Panel A and B of Table 5 overlap for a subset of CEOs. Both samples include CEOs that are board chairpersons for only one of the two firms they lead during the sample period. If anything, the overlap might bias the results against finding a difference in the significance of the F-stats for the two samples.
} 
models effectively address this source of bias if the characteristic that is omitted from the model specification is time-invariant or at most slow moving. Another possibility is an endogenous relation affecting the results of this study. Rather than executives implementing governance changes, for example, firms might optimally choose managers who are the best match for their corporate governance structures. We partially control for this possible issue in the main regressions by lagging the independent variables by one year.

In this section, we address these concerns more thoroughly in two additional ways. We first consider two subsamples of CEOs (chairs) who worked in each of their firms for at least two years. In a similar vein to Richardson et al. (2003), we essentially focus on those executives who might have an improved ability to influence the governance policy variables due to a longer tenure. In one subsample we exclude the observations corresponding to the first year of each tenure, in the second subsample we exclude the observations corresponding to the last year of each tenure. CEOs and chairs are likely to actively implement changes after at least one year since they assume their position. If CEOs and chairs are going to actively change governance policies, the managerial fixed effects for the sample without the first year should be stronger than for the sample that excludes the last year of tenure. If, instead, the results of this study are due to the effect of unobserved factors or firms matching their new governance policies with CEOs and chairs with similar philosophies, there should not be any difference in the significance of any of the fixed effects when either excluding the first year or last year of tenure from the sample.

Table 6, Panel A, presents the results of this robustness test for CEO effects. For the regressions that have board independence and modified G-index as dependent variables, CEO effects are significant at lower significance levels when the first year is excluded than they are when the last year is excluded. While CEO effects are never significant for board size 
regressions, they are significant at the $1 \%$ level for the CEO-chair duality regressions excluding either the first or the last year. Adjusted $\mathrm{R}^{2}$ and pseudo $\mathrm{R}^{2}$ of regression specifications with CEO fixed effects are always higher when the first tenure year is excluded.

Panel B presents the results for chair effects. When board independence is the dependent variable and the first year of tenure is excluded, chair effects are significant at higher, not lower, significance levels. Chair effects are only significant for board size and CEO-chair duality regressions when the first year is excluded and are never significant for the modified G-index regressions. Adjusted $\mathrm{R}^{2}$ is the same for board characteristics regression specifications with chair fixed effects when either the first or the last year is excluded. Adjusted $\mathrm{R}^{2}$ and pseudo $\mathrm{R}^{2}$ are higher for the modified G-index and the CEO-chair duality regressions, respectively, when the first year is excluded. Since these results provide only partial evidence inconsistent with an endogenous relation between managerial heterogeneity and governance practices, we conduct a second robustness test to reduce our concerns.

Following Bertrand and Schoar (2003), our next robustness test consists of a parametric analysis based on residual regression to examine the persistence of managerial effects on governance. We first estimate firm-year residuals by regressing the governance variables of interest on the time-varying firm controls and year fixed effects. We then average these annual residuals for each CEO-firm or chair-firm cluster. This executive's average residual essentially represents the unobservable executive specific effects on governance characteristics for each executive-firm pair. In the last step of this test, we regress the executive's average residual in his second firm on his average residual in the first firm. We report the results in the "real data" columns of Table 7. We find a positive and statistically significant relationship between a CEO or chair residual in his last job and his residual in his first job for all the governance variables, 
with the sole exception of the modified G-index for CEOs. The results of this test present strong evidence consistent with a persistence of the CEO and chair effects across all firms which they are employed in after controlling for firm characteristics and time effects. However, this test does not univocally imply an active influence of managers on their companies. Suppose a model of the world where managers have no specific skills or styles but boards mistakenly believe otherwise. The CEOs or the chairs in our sample could coincidentally be appointed by two firms with similar governance policies.

To dispel this concern we analyze the precise timing of the observed changes in corporate policies. If CEOs and board chairs actively shape internal corporate governance, the governance changes will only take place after the appointment. We implement a placebo method similar to Bertrand and Schoar (2003). We calculate average residuals in governance structures as described above with the exception of assuming that each manager in our data set joins his second firm three years prior to the actual appointment date and leaves that firm just prior of the actual appointment date. ${ }^{6} \mathrm{We}$ then regress these average pre-appointment residuals for the second firm on the true average residuals for the first firm. If the new CEO or chairperson is personally responsible for the change in governance policies instead of been coincidentally appointed by a firm with similar policies as the previous one, the "placebo" regressions should have lower adjusted $\mathrm{R}^{2}$ than the "real" residual regressions. We present the results in the "placebo data" columns of Table 7. Contrary to the "real data" coefficients, the "placebo data" coefficients are not statistically significant and the regressions' adjusted $\mathrm{R}^{2}$ are consistently lower and for the most part very close to zero. These results provide strong evidence confirming that the changes in corporate governance take place when the new CEO or chair arrives at the

\footnotetext{
${ }^{6}$ For instance, if a CEO joins his second firm (firm B) in 2004, we calculate pre-appointment residuals using firm B data for the 2001-2003 period when, in reality, a different CEO was at the helm of the firm.
} 
new company rather than taking place independently from the executive's arrival. ${ }^{7}$

\section{Conclusions}

Several studies examine how firm and institutional characteristics affect corporate governance structure and policies. However, little is known empirically in regards to the influence of executive personality traits and managerial styles (i.e., managerial heterogeneity) on corporate governance. In this study we investigate if $\mathrm{CEO}$ and board chair fixed effects can explain the variation in corporate governance characteristics over firm characteristics and firm effects. We find that both CEO and board chair fixed effects are significant determinants of board structure (board size and independence) and CEO-chair duality. Powerful CEOs, those executives who hold both the CEO and chair of the board positions, have the strongest effect on governance policies.

Our results suggest that changes in governance characteristics take place after the new CEO or chair arrives in the new company. While they may be interpreted as evidence of the influence of managerial heterogeneity on governance characteristics, an alternative interpretation is that a company becomes attractive to managers after announcing or contemplating changes in governance structures that are consistent with their managerial style. ${ }^{8}$ Under either interpretation, our results support the notion that $\mathrm{CEO}$ and chairperson heterogeneity significantly explains some of the variation in corporate governance.

We also examine if the managerial effects have a diminished significance for the period

\footnotetext{
${ }^{7} \mathrm{We}$ also calculate the variation in governance measures during the tenure of the CEOs/chairs in our sample and compare them with the changes during the tenure of the previous CEOs/chairs. We find significantly greater changes in governance variables during the tenure of CEOs/chairs in our sample. The results of this test provide additional evidence that changes in corporate governance take place when the new CEO or chair arrives.

${ }^{8}$ We thank the referee for suggesting this alternative interpretation.
} 
following the implementation of the Sarbanes-Oxley act, and NYSE and Nasdaq governance regulations. These regulations had the objective, among others, of reducing the CEO influence on board decisions to improve board monitoring and internal governance practices. The evidence presented in this study suggests that CEOs did not experience a reduction in their influence on board composition after the enactment of these regulations.

While our study shows that CEO and board chair fixed effects are statistically significant determinants of certain corporate governance choices, the exact channels through which managerial styles affect governance remain an unaddressed issue. This relation possibly reflects differences in managers' specific characteristics and abilities, such as leadership, personal intellectual, motivational, and interpersonal traits as suggested by Kaplan et al. (2012). Governance changes may result either from managers' imposition or from firms choices based on their managerial styles. We believe that this and other unanswered questions that arise from our results represent interesting areas for future theoretical and empirical research. 


\section{References}

Adams, R.B., Almeida, H., and Ferreira, D., 2005. Powerful CEOs and their impact on corporate performance. Rev. Financ. Stud. 18, 1403-1432.

Bargeron, L.L., Lehn, K.M., and Zutter, C.J., 2010. Sarbanes-Oxley and corporate risk-taking. J. Acc. Econ. 49, 34-52.

Berle, A.A., Means, G.C.,1932. The modern corporation and private property, New York: Macmillan.

Bertrand, M., Schoar, A., 2003. Managing with style: The effect of managers on firm policies. Quart. J. Econ. 118, 1169-1208.

Boone, A.L., Field, L.C., Karpoff, J.M., Raheja, C.G., 2007. The determinants of corporate board size and composition: An empirical analysis. J. Financ. Econ. 85, 66-101.

Chi, J., 2005. Understanding the endogeneity between firm value and shareholder rights. Finan. Manage. 34, 65-76.

Coles, J.L., Daniel, N.D., Naveen, L., 2008. Boards: Does one size fit all? J. Financ. Econ. 87, 329-356.

Core, J.E., Holthausen, R.W., Larcker, D. F., 1999. Corporate governance, CEO compensation, and firm performance. J. Financ. Econ. 51, 371-406.

Cyert, R.M., Kang, S., Kumar, P., 2002. Corporate governance, takeovers, and top-management compensation: Theory and evidence. Manage. Sci. 48, 453-469.

Fama, E., and Jensen, M.C., 1983. Separation of ownership and control. J. Law Econ. 26, 301325.

Felton, R.F., 2004a. A new era in corporate governance. McKinsey Q. 2, 28-37. 57. , 2004b. Splitting Chairs: Should CEOs give up the Chairman's role? McKinsey Q. 4, 49-

Florou, A., 2005. Top director shake-up: The link between chairman and CEO dismissal in the UK. J. Bus. Financ. Account. 32, 97-128.

Frank, M.Z., Goyal, V.K., 2009. Corporate Leverage: How much do managers really matter? Working Paper, University of Minnesota. 
Galbraith, J.K., 1967. The new industrial state, Boston: Houghton Mifflin.

Gompers, P.A., Ishii, J., Metrick, A., 2003. Corporate governance and equity prices. Quart. J. Econ. 118, 107-155.

Ghosh, A., Marra, A., and Moon, D.,2010. Corporate boards, audit committees, and earnings management: Pre- and post-SOX evidence. J. Bus. Financ. Account. 37, 1145-1176.

Goyal, V.K., Park, C.W., 2002. Board leadership structure and CEO turnover. J. Corp. Financ. 8, 49-66.

Graham, J.R., Li, S., and Qiu, J., 2011. Managerial attributes and executives compensation. Rev. Financ. Stud., forthcoming.

Hermalin, B.E., and Weisbach, M.S., 1998. Endogenously chosen boards of directors and their monitoring of the CEO. Am. Econ. Rev. 88, 96-118.

Jensen, M.C., 1993. The modern industrial revolution, exit, and the failure of internal control systems. J. Finance 48, 831-880.

Kang, Q., Liu, Q., Qi, R., 2010. The Sarbanes-Oxley act and corporate investment: A structural assessment. J. Financ. Econ. 96, 291-305.

Kaplan, S.N., Klebanov, M.M., Sorensnen, M., 2012. Which CEO characteristics and abilities matter? J. Finance 67, 973-1007.

Linck, J.S., Netter, J.M., Yang, T., 2008. The determinants of board structure. J. Financ. Econ. 87, 308-28.

Link, J.S., Netter, J.M., Yang, T., 2009. The effects and unintended consequences of the Sarbanes-Oxley act on the supply and demand for directors. Rev. Financ. Stud. 22, 3287-328.

Lipton, M., Lorsch, J.W., 1992. A modest proposal for improved corporate governance. Bus. Law. 48, 59-77.

Mace, M. 1971. Directors, Myth, and Reality, Boston: Harvard Business School Press.

Mason, E.S., 1958. The apologetics of 'managerialism'. J. Bus. 31, 1-11.

Richardson, S., Tuna, I., Wysocki, P.D., 2003. Accounting for taste: Board member preferences and corporate policy choices. Working Paper, London Business School. 
Shivdasani, A., and Yermack, D., 1999. CEO involvement in the selection of new board members: An empirical analysis. J. Finance 54, 1829-1853.

Yermack, D.L., 1996. Higher market valuation of companies with a small board of directors. $J$. Financ. Econ. 40, 185-211. 
Table 1

Number of Firms and Executives in the Sample

This table presents descriptive statistics on the number of CEOs, chairpersons, and firms in our sample. Panel A shows how many executives vested the role of CEOs or chairpersons in at least two different firms during our sample period (1996-2009). Panel B shows the number of sample firms with one CEO or chairperson, two different CEOs or chairpersons, or three different CEOs or chairpersons in our sample between 1996 and 2009.

\begin{tabular}{|c|c|c|c|}
\hline \multicolumn{4}{|c|}{ Panel A: Number of executives per number of firms } \\
\hline & n. of firms & n. of CEOs & n. of chairs \\
\hline & 2 & 133 & 224 \\
\hline & 3 & 6 & 23 \\
\hline & 4 & 1 & 1 \\
\hline & 5 & 0 & 0 \\
\hline & 6 & 0 & 1 \\
\hline Total & & 140 & 249 \\
\hline \multicolumn{4}{|c|}{ Panel B: Number of firms per number of executives } \\
\hline n. of CEOs & n. of firms & n. of chairs & n. of firms \\
\hline 1 & 246 & 1 & 433 \\
\hline 2 & 18 & 2 & 47 \\
\hline 3 & 2 & 3 & 0 \\
\hline Total & 266 & & 480 \\
\hline
\end{tabular}


Table 2

Descriptive Statistics

This table presents means, medians and standard deviations of firm and governance characteristics for the CEO sample and the chair sample. The statistics reported in this table refer to firm averages across time. The sample period goes from 1996 to 2009.

\begin{tabular}{|lcccccc|}
\hline \multicolumn{3}{|c}{ Panel A; Firm Characteristics } & \multicolumn{3}{c}{ Chair Sample } \\
& Mean & Median & St Dev & Mean & Median & St Dev \\
FCF & 0.0772 & 0.0706 & 0.0782 & 0.0771 & 0.0748 & 0.0723 \\
MVE & 9,606 & 2,264 & 20,464 & 8,860 & 2,406 & 18,965 \\
MTB & 3.147 & 2.130 & 3.201 & 3.012 & 2.252 & 2.556 \\
LTD & 0.1995 & 0.1770 & 0.1722 & 0.2220 & 0.1982 & 0.1708 \\
ADJEBIT & 0.0548 & 0.0282 & 0.0993 & 0.0550 & 0.0321 & 0.0915 \\
NSEGS & 2.33 & 2.00 & 1.52 & 2.32 & 2.00 & 1.39 \\
STDEV & 0.1206 & 0.1055 & 0.0648 & 0.1147 & 0.1019 & 0.0574 \\
AGE & 22.709 & 16 & 20.726 & 21.107 & 14 & 19.837 \\
Panel B: Governance & Characteristics & & & & \\
& & CEO Sample & & & Chair Sample \\
board size & Mean & Median & St Dev & Mean & Median & St Dev \\
independents & 9.86 & 9.00 & 2.96 & 9.83 & 9.50 & 2.90 \\
insiders & 6.54 & 6 & 2.72 & 6.58 & 6 & 2.61 \\
CEO\&Chair & 1.83 & 2 & 1.00 & 1.76 & 1.50 & 1.03 \\
Modified G-index & 0.66 &. & 0.44 & 0.49 & $\cdot$ & 0.46 \\
\end{tabular}


Table 3

\section{CEO and Chair Fixed Effects Regressions}

This table presents results from fixed effects panel regressions. Panel A presents CEO fixed effects regressions on the CEO sample. Panel B presents chairperson fixed effects regressions on the chairperson sample. The sample spans from 1996 to 2009 with the exception of the Modified G-index regressions for which the sample spans from 1996 to 2006 due to data availability. The independent variables of the regressions include FCF, $\ln (\mathrm{MVE}), \mathrm{MTB}, \mathrm{LTD}, \mathrm{ADJEBIT}$, nsegs, stdev, $\ln (1+\mathrm{age})$. The fixed effects are year and firm in column 3 and year, firm, and CEO (in panel A) or chairman (in Panel B) in column 4. Reported are the F-tests for the joint significance of the CEO (or chair) fixed effects. For each F-test we report the value of the F-statistic and the p-value.

\begin{tabular}{|c|c|c|c|}
\hline \multicolumn{4}{|c|}{ Panel A: CEO Effects on Governance Policies } \\
\hline \multirow{3}{*}{ Board Independence } & & $\begin{array}{c}\text { Year } \\
\text { and firm } \\
\text { effects }\end{array}$ & CEO effects \\
\hline & F-stat & & $2.21(0.009)$ \\
\hline & $\operatorname{Adj} R^{2}$ & 0.88 & 0.90 \\
\hline \multirow{2}{*}{ Board Size } & F-stat & & $1.58(0.080)$ \\
\hline & Adj $R^{2}$ & 0.88 & 0.89 \\
\hline \multirow{2}{*}{ CEO - Chair Duality } & Chi-square & & $222.38(0.000)$ \\
\hline & Pseudo R2 & 0.27 & 0.82 \\
\hline \multirow{2}{*}{ Modified G-index } & F-stat & & $2.35(0.015)$ \\
\hline & Adj $R^{2}$ & 0.96 & 0.97 \\
\hline \multicolumn{4}{|c|}{ Panel B: Chairperson Effects on Governance Policies } \\
\hline \multirow{3}{*}{ Board Independence } & & $\begin{array}{c}\text { Year } \\
\text { and firm } \\
\text { effects }\end{array}$ & Chair effects \\
\hline & F-stat & & $2.06(0.002)$ \\
\hline & Adj $R^{2}$ & 0.86 & 0.87 \\
\hline \multirow{2}{*}{ Board Size } & F-stat & & $1.81(0.008)$ \\
\hline & $\operatorname{Adj} R^{2}$ & 0.85 & 0.86 \\
\hline \multirow{2}{*}{ CEO - Chair Duality } & Chi-square & & $757.78(0.000)$ \\
\hline & Pseudo $\mathrm{R}^{2}$ & 0.49 & 0.80 \\
\hline \multirow{2}{*}{ Modified G-index } & F-stat & & $1.95(0.032)$ \\
\hline & Adj $R^{2}$ & 0.94 & 0.95 \\
\hline
\end{tabular}




\section{Table 4}

\section{CEO and Chair Fixed Effects Regressions pre- and post-SOX}

This table presents results from fixed effects panel regressions for 1996-2002 (pre-SOX period) and 20032009 (post-SOX period). Panel A presents CEO fixed effects regressions on the CEO sample. Panel B presents chairperson fixed effects regressions on the chairperson sample. The independent variables of the regressions include FCF, $\ln (\mathrm{MVE}), \mathrm{MTB}$, LTD, ADJEBIT, nsegs, stdev, $\ln (1+$ age $)$.. The fixed effects are year and firm in columns 3 and 5; and year, firm, and CEO (in panel A) or chairperson (in Panel B) in columns 4 and 6 . Reported are the F-tests for the joint significance of the CEO (or chair) fixed effects. For each F-test we report the value of the F-statistic and the p-value.

\begin{tabular}{|c|c|c|c|c|c|}
\hline \multirow{4}{*}{ Board Independence } & & $\begin{array}{c}\text { Year and } \\
\text { firm } \\
\text { effects }\end{array}$ & CEO effects & $\begin{array}{l}\text { Year and } \\
\text { firm } \\
\text { effects }\end{array}$ & CEO effects \\
\hline & & \multicolumn{2}{|c|}{ 1996-2002 } & \multicolumn{2}{|c|}{ 2003-2009 } \\
\hline & F-stat & & $1.24(0.283)$ & & $4.07(0.002)$ \\
\hline & Adj $R^{2}$ & 0.92 & 0.93 & 0.92 & 0.93 \\
\hline \multirow{2}{*}{ Board Size } & F-stat & & $1.38(0.216)$ & & $2.00(0.069)$ \\
\hline & Adj $R^{2}$ & 0.92 & 0.93 & 0.90 & 0.91 \\
\hline \multirow{2}{*}{ CEO - Chair Duality } & Chi-Square & & $107.40(0.000)$ & & $53.98(0.000)$ \\
\hline & Pseudo $\mathrm{R}^{2}$ & 0.23 & $\begin{array}{r}0.88 \\
6-2002\end{array}$ & 0.26 & $\begin{array}{r}0.89 \\
3-2006\end{array}$ \\
\hline \multirow{2}{*}{ Modified G-index } & F-stat & & $3.19(0.010)$ & & $0.41(0.746)$ \\
\hline & Adj $R^{2}$ & 0.96 & 0.97 & 0.99 & 0.99 \\
\hline \multicolumn{6}{|c|}{ Panel B: Chairperson Effects on Governance Policies } \\
\hline & & $\begin{array}{c}\text { Year and } \\
\text { firm } \\
\text { effects }\end{array}$ & CEO effects & $\begin{array}{c}\text { Year and } \\
\text { firm } \\
\text { effects }\end{array}$ & CEO effects \\
\hline & & & $6-2002$ & & $3-2009$ \\
\hline \multirow{2}{*}{ Board Independence } & F-stat & & $1.15(0.190)$ & & $3.07(0.003)$ \\
\hline & Adj $R^{2}$ & 0.91 & 0.91 & 0.86 & 0.87 \\
\hline \multirow{2}{*}{ Board Size } & F-stat & & $(0.054)$ & & $0.88(0.547)$ \\
\hline & $\operatorname{Adj} R^{2}$ & 0.91 & 0.92 & 0.87 & 0.88 \\
\hline \multirow{2}{*}{ CEO - Chair Duality } & Chi-Square & & $321.81(0.000)$ & & $126.79(0.000)$ \\
\hline & Pseudo $\mathrm{R}^{2}$ & 0.55 & $6-2002$ & 0.54 & $\begin{array}{l}0.82 \\
3-2006\end{array}$ \\
\hline Modified G-index & F-stat & & $3.06(0.006)$ & & $0.33(0.802)$ \\
\hline
\end{tabular}




\begin{tabular}{|llllll|}
\hline Adj R $^{2}$ & 0.94 & 0.95 & 0.98 & 0.98 \\
\hline
\end{tabular}




\section{Table 5}

\section{CEO and Chair Fixed Effects Regressions by Type}

This table presents results from fixed effects panel regressions. Panel A presents fixed effects for CEOs that are also chairperson of their firm's board for at least one of the two firms they lead during the sample period ("Powerful CEO"). Panel B presents fixed effects for CEOs that are not chairperson of their firm's board for at least one of the two firms they lead during the sample period ("Pure CEO"). Panel C presents fixed effects for chairpersons that are not CEO of the same firm for at least one of the two firms for which they chaired the board during the sample period ("Pure Chair"). The independent variables of the regressions include FCF, $\ln (\mathrm{MVE}), \mathrm{MTB}, \mathrm{LTD}, \mathrm{ADJEBIT}$, nsegs, stdev, $\ln (1+\mathrm{age})$.. The fixed effects are year and firm in columns 3; and year, firm, and CEO (or chair) in columns 4. Reported are the F-tests for the joint significance of the CEO (or chair) fixed effects. For each F-test we report the value of the Fstatistic and the p-value.

\begin{tabular}{|c|c|c|c|}
\hline \multicolumn{4}{|c|}{ Panel A: "Powerful CEO" Effects on Governance Policies } \\
\hline & & $\begin{array}{c}\text { Year and firm } \\
\text { effects }\end{array}$ & CEO effects \\
\hline \multirow{2}{*}{ Board Independence } & F-stat & & $3.48(0.001)$ \\
\hline & $\operatorname{Adj} R^{2}$ & 0.86 & 0.88 \\
\hline \multirow{2}{*}{ Board Size } & F-stat & & $1.87(0.074)$ \\
\hline & Adj $R^{2}$ & 0.86 & 0.87 \\
\hline \multirow{2}{*}{ Modified G-index } & F-stat & & $8.57(0.000)$ \\
\hline & Adj $R^{2}$ & 0.82 & 0.83 \\
\hline \multicolumn{4}{|c|}{ Panel B: "Pure CEO" Effects on Governance Policies } \\
\hline & & $\begin{array}{c}\text { Year and firm } \\
\text { effects }\end{array}$ & CEO effects \\
\hline \multirow{2}{*}{ Board Independence } & F-stat & & $0.60(0.732)$ \\
\hline & Adj $R^{2}$ & 0.91 & 0.91 \\
\hline \multirow{2}{*}{ Board Size } & F-stat & & $1.73(0.130)$ \\
\hline & $\operatorname{Adj} R^{2}$ & 0.92 & 0.92 \\
\hline \multirow{2}{*}{ Modified G-index } & F-stat & & $5.96(0.000)$ \\
\hline & Adj $R^{2}$ & 0.98 & 0.98 \\
\hline
\end{tabular}




\begin{tabular}{|c|c|c|c|}
\hline & & $\begin{array}{c}\text { Year and firm } \\
\text { effects }\end{array}$ & CEO effects \\
\hline \multirow{2}{*}{ Board Independence } & F-stat & & $1.20(0.263)$ \\
\hline & Adj $R^{2}$ & 0.85 & 0.85 \\
\hline \multirow{2}{*}{ Board Size } & F-stat & & $1.54(0.086)$ \\
\hline & $\operatorname{Adj} R^{2}$ & 0.84 & 0.85 \\
\hline \multirow{2}{*}{ Modified G-index } & F-stat & & $3.24(0.007)$ \\
\hline & $\operatorname{Adj} R^{2}$ & 0.92 & 0.93 \\
\hline
\end{tabular}




\section{Table 6}

\section{Robustness Test - Truncated Sample: First Year versus Last Year Exclusion}

This table presents results from fixed effects panel regressions after either excluding the first year or the last year of the CEO (chairperson) tenure in each firm. Panel A presents CEO fixed effects regressions on the CEO sample. Panel B presents chairperson fixed effects regressions on the chairperson sample. The sample spans from 1996 to 2009 with the exception of the Modified G-index regressions for which the sample spans from 1996 to 2006 due to data availability. The independent variables of the regressions include FCF, $\ln (\mathrm{MVE})$, MTB, LTD, ADJEBIT, nsegs, stdev, $\ln (1+$ age). In addition to CEO (chair) fixed effects the regressions includes also year and firm fixed effects. We report the F-tests for the joint significance of the CEO (or chair) fixed effects. For each F-test we report the value of the F-statistic and the p-value.

\begin{tabular}{llcc} 
Panel A: CEO Effects on Governance Policies \\
& \multicolumn{4}{c}{ CEO effects } & CEO effects \\
& & $\begin{array}{c}\text { Excluding } \\
\text { first year }\end{array}$ & $\begin{array}{c}\text { Excluding } \\
\text { last year }\end{array}$ \\
Board Independence & F-stat & $2.15(0.032)$ & $2.06(0.041)$ \\
& Adj R & 0.91 & 0.90 \\
Board Size & & & $0.98(0.454)$ \\
F-stat & $1.33(0.230)$ & 0.89 \\
CEO - Chair Duality & Chi-Square & $94.69(0.000)$ & $94.83(0.000)$ \\
& Pseudo R & 0.99 & 0.76 \\
& & & $2.09(0.087)$ \\
Modified G-index & F-stat & $4.40(0.003)$ & 0.97
\end{tabular}

Panel B: Chairperson Effects on Governance Policies

$\begin{array}{llcc} & & \text { Chair effects } & \text { Chair effects } \\ & & \begin{array}{c}\text { Excluding } \\ \text { first year }\end{array} & \begin{array}{c}\text { Excluding } \\ \text { last year } \\ \text { Board Independence }\end{array} \\ & \text { F-stat } & 1.90(0.032) & 2.08(0.022) \\ & \text { Adj R } & 0.87 & 0.87 \\ \text { Board Size } & \text { F-stat } & 1.84(0.039) & 1.13(0.335) \\ & \text { Adj R } & 0.87 & 0.87 \\ \text { CEO - Chair Duality } & \text { Chi-Square } & 414.27(0.000) & 77.49(0.650) \\ & \text { Pseudo R } & 0.75 & 0.52 \\ \text { Modified G-index } & \text { F-stat } & 0.26(0.603) & 0.40(0.526)\end{array}$


Adj $R^{2}$

0.95

0.94 


\section{Table 7}

Robustness Test - Persistence of CEO and Chair Effects: Real Data versus Placebo Data

This table presents results of residual regressions with real data and placebo data. Each entry in the table corresponds to a different regression. For the "real data" regressions we regress average residual in the CEO's (chair's) second firm on his average residual in his first firm. For the "placebo data" regressions we regress average residual in his second firm for the three years prior the CEO (chair) joining that firm on his true average residual in his first firm. Below each coefficient, we present the p-values in parenthesis and the estimated $\mathrm{R}^{2}$ in squared brackets.

\begin{tabular}{|lcccc|}
\hline \multirow{4}{*}{ Board Independence } & \multicolumn{2}{c}{ CEOs } & \multicolumn{2}{c|}{ Board Chairs } \\
& Real Data & Placebo Data & Real Data & Placebo Data \\
& 0.280 & 0.114 & 0.233 & 0.233 \\
& $(0.003)$ & $(0.340)$ & $(0.000)$ & $(0.152)$ \\
Board Size & {$[0.11]$} & {$[0.01]$} & {$[0.10]$} & {$[0.05]$} \\
& 0.243 & 0.072 & 0.178 & 0.113 \\
& $(0.006)$ & $(0.536)$ & $(0.014)$ & $(0.579)$ \\
CEO - Chair Duality & {$[0.11]$} & {$[0.01]$} & {$[0.07]$} & {$[0.01]$} \\
& 0.170 & -0.041 & 0.108 & -0.001 \\
Modified G-index & $(0.065)$ & $(0.742)$ & $(0.091)$ & $(0.914)$ \\
& {$[0.07]$} & {$[0.00]$} & {$[0.07]$} & {$[0.00]$} \\
& 0.134 & 0.005 & 0.202 & 0.009 \\
& $(0.315)$ & $(0.813)$ & $(0.010)$ & $(0.795)$ \\
\hline
\end{tabular}

